J. Amer. Soc. Hort. ScI. 116(3):421-425. 1991.

\title{
Tomato Seedling Growth, Earliness, Yield, and Quality following Pretransplant Nutritional Conditioning and Low Temperatures
}

\author{
Regina R. Melton ${ }^{1}$ and Robert J. Dufault ${ }^{2}$ \\ Coastal Research and Education Center, Department of Horticulture, Clemson University, 2865 \\ Savannah Highway, Charleston, SC 29414 \\ "Additional index words. Lycopersicon esculentum, Solanaceae, stress, transplant, hardening, chilling
}

\begin{abstract}
Sunny' tomato (Lycopersicon esculentum Mill.) seedlings were pretransplant nutritionally conditioned $(\mathrm{PNC})$ in 1988 and 1989 with factorial combinations of $\mathrm{N}$ from 100 to $300 \mathrm{mg} \cdot \mathrm{liter}^{-1}$ and $P$ from 10 to $70 \mathrm{mg} \cdot \mathrm{liter}$. In 1988, all conditioned seedlings were exposed to 12 hours of $2 \mathrm{C}$ for eight consecutive nights before transplanting. In 1989, half of the conditioned plants were exposed to a low-temperature treatment of 8 days with 12-hour nights at $2 \mathrm{C}$ and 12-hour days in a warm greenhouse $(19 \mathrm{C} / 26 \mathrm{C}$, night/day). In both years, as $\mathrm{N}$ PNC increased to 200 mg-liter ${ }^{-1}$, seedling growth increased. Increasing P PNC from 10 to $40 \mathrm{mg}^{-l i t e r}{ }^{-1}$ increased seedling growth, but only in 1988. In both years, P PNC did not affect yields. Low-temperature exposure in 1989 decreased seedling growth in comparison to those held in a warm greenhouse $(19 \mathrm{C} / 26 \mathrm{C}$, day/night). In 1988, first harvest yields were not affected by N PNC; however, in 1989, as $\mathrm{N}$ increased to $200 \mathrm{mg} \cdot \mathrm{liter}^{-1}$, early yields increased. In 1988, total yields increased wit $h$ N PNC from 100 to 200 mg·liter and in 1989 with $N$ at 50 to $100 \mathrm{mg}^{-1} \cdot \mathrm{liter}^{-1}$, with no further increases from 100 to $200 \mathrm{mg} \cdot$ liter-1. $^{-1}$ Low-temperature exposure had no effect on earliness, yield, or quality. A PNC regime combining at least $200 \mathrm{mg} \mathrm{N} / \mathrm{liter}$ and up to $10 \mathrm{mg}$ P/liter should be used to nutritionally condition 'Sunny' tomato seedlings to enhance yield.
\end{abstract}

Most tomato fieIds in coastal South Carolina are established using greenhouse-grown transplants. Once planted, the seedlings may be exposed to near chilling temperatures for weeks before fields warm. Low-temperature stresses may delay flowering, fruiting, and possibly reduce total yields and quality. We hypothesized that earliness and overall yields would be improved using pretransplant nutritional conditioning (PNC), whereby seedlings are nutritionally conditioned during greenhouse transplant production to enable them to better tolerate transplant stresses and enhance earliness.

PNC has been shown to have long-term effects on muskmelon and tomato (Dufault, 1986; Weston and Zandstra, 1989). Although muskmelon transplant shock increased as PNC levels increased, recovery from shock was faster with higher PNC regimes (Dufault, 1986). Earliness was affected by high vs. low PNC for muskmelon (Dufault, 1986) and tomato (Weston and Zandstra, 1989), but total yields were not affected.

The influence of PNC on improving cold tolerance of tomatoes at near freezing temperatures is unknown. Low temperatures may reduce survival and possibly delay early tomato yields (Brasher and Westover, 1937). However, seedlings conditioned with a 48-h low-temperature exposure (12.5C) were more coldtolerant than those conditioned for $3 \mathrm{~h}$ at the same temperature (Wheaton and Morris, 1968). Tomato productivity increased in greenhouse studies by exposing seedlings to chilling (10-13C) temperatures, especially in conjunction with high $\mathrm{N}$ nutrition (Wittwer and Teubner, 1957). The objectives of our study were

Received for publication 14 Aug. 1990. Technical contribution no. 3154 of the South Carolina Experiment Station, Clemson Univ. This study was funded from the USDA grant (CSRS-85-CSRS-2-2541) "Agricultural Adjustment in the Southeast through Alternative Cropping Systems". The cost of publishing this paper was defrayed in part by the payment of page charges. Under postal regulations, this paper therefore must be hereby marked advertisement solely to indicate this fact.

'Graduate Student.

'Associate Professor. to determine the effects of $\mathrm{N}$ and $\mathrm{P}$ PNC and low temperature on tomato seedling growth, earliness, yield, and fruit quality.

\section{Materials and Methods}

Influence of NP and low temperatures on seedling growth. 'Sunny' tomato seeds were planted on 2 Mar. 1988 in quartered Todd flats (Speedling, Sun City, Fla.), (size 150, volume 30.5 $\mathrm{cm}^{3}$ ) filled with Sogemix \#3 peatmoss/vermiculite medium (Sogevex, Apopka, Fla.). A soil test indicated (in $\mathrm{mg} \cdot$ liter $^{-1}$ ) $8 \mathrm{~N}$ $28 \mathrm{P}-103 \mathrm{~K}$ and a $5.7 \mathrm{pH}$. The range of pretransplant nutritional regimes were based on a previous greenhouse study (Melton and Dufault, 1991). Solutions consisted of factorial combinations of $\mathrm{N}$ from calcium nitrate at 100, 200, and $300 \mathrm{mg} \cdot \mathrm{liter}^{-}$ and $\mathrm{P}$ from calcium phosphate at 10,40 , and $70 \mathrm{mg} \cdot$ liter $^{-1}$. Additionally, the following were included in all nutrient solutions: $\mathrm{K}$ (potassium sulfate at $100 \mathrm{mg} \cdot \mathrm{liter}^{-1}$ ); magnesium sulfate $\left(70 \mathrm{mg} \cdot\right.$ liter $\left.^{-1}\right)$; and calcium carbonate $\left(471 \mathrm{mg} \cdot\right.$ liter $^{-1}$. included to prevent a calcium compounding effect). Micronutrients were supplied in all nutrient solutions with Soluble Trace Element Mix (Peter's Fertilizer Products, W.P. Grace \& Co., Allentown, Pa.) at the recommended rate of $313 \mathrm{mg} \cdot$ liter $^{-1}$. The $\mathrm{pH}$ of each solution was adjusted to 7.0 using $\mathrm{H}_{2} \mathrm{SO}_{\mathrm{d}}$ or $\mathrm{NaOH}$.

The flats were placed in a greenhouse and maintained at a mean of 19C/26C (night/day). Each replication (a quartered flat) consisted of 32 seedlings. The nine NP PNC treatments were replicated four times and arranged in a randomized complete block design. The first nutrient application was made on 16 Mar. 1988 at the second true-leaf stage, 14 days after seeding. The flats were floated in nutrient solutions in $38 \times 25 \times 9$ $\mathrm{cm}$ plastic storage boxes (Max Klein Co., Baraboo, Wis.) for $1 \mathrm{~h}$, then drained for $1 \mathrm{~h}$, and returned to their respective bench locations. Nutrient solutions were applied three times/week until 25 Mar., when at least one treatment across all replications had reached minimal transplanting stage $(\approx 15$ to $20 \mathrm{~cm}$ height with five true leaves). A total of five PNC treatments were made. 
On 27 Mar., the seedlings in all the PNC treatments were placed for eight consecutive nights in darkness at $\approx 2 \mathrm{C}$ in a cooler from 1900 to $0700 \mathrm{HR}$ and returned to the greenhouse $(26 \pm 6 \mathrm{C})$ from 0700 to $1900 \mathrm{HR}$ to simulate low-temperature extremes possible in the field. The seedlings (including those held in the greenhouse) were not nutritionally conditioned during Iow-temperature exposure but were irrigated with tap water only.. Although we attempted to illuminate the seedlings in the coolers during low-temperature stress treatments, heat from the lights within the coolers increased unit temperatures significantly. Hence, Iow-temperature imposition was scheduled to occur in darkness to reduce the number of hours of light deprivation. The effect of the increased periods of darkness imposed during low-temperature stress on seedling growth is unknown.

Nine plants were randomly chosen from each flat for seedling growth analysis on 4 Apr. 1988. Variables measured included: shoot fresh weight; stem diameter (at cotyledonary node); expanded true leaf number (leaves with clearly visible petioles); leaf area per seedling, including petiole (LI-COR LI-3100 leaf area meter; LI-COR, Lincoln, Neb.); and shoot and root dry weights per treatment plot (dried for $24 \mathrm{~h}$ at $65 \mathrm{C}$ ). One leaf disk $(0.31 \mathrm{~cm}$ ') from the second true-leaf tip of five plants each per treatment was removed with a hole punch, composite, and total chlorophyll was determined (Moran, 1982). Chlorophyll content was used to quantify the visible differences in greenness among the PNC treatments.

Growth data were subjected to a factorial analysis of variance (ANOVA). The relative importance of $\mathrm{N}$ and $\mathrm{P}$ on tomato seedling growth was determined by partitioning the total sum of squares for treatments into main and interaction effects and by expressing their individual contribution to variation as a percentage of the total sum of squares for the model (composed of only those sources of variation in the ANOVA).

Refinements of the experimental treatments used in 1988 were necessary in 1989 to clarify the meaning and precision of the experiments. Ineffectual treatments, such as the $70 \mathrm{mg} \mathrm{P}$ and $300 \mathrm{mg}$ N/liter were abandoned. Generally, similar experimental procedures were followed in 1989 as in 1988, with the following modifications. The Seeds were planted on 17 Mar. 1989. Nutrient concentrations included $\mathrm{N}$ rates at 50, 100, and 200 $\mathrm{mg} \cdot$ liter $^{-1}$ and $\mathrm{P}$ rates at 10 and $40 \mathrm{mg} \cdot \mathrm{liter}^{-1}$. The Ca level was adjusted to $309 \mathrm{mg} \cdot \mathrm{liter}^{-1}$ In addition, two flats per PNC treatment were used; one flat was exposed to low temperatures at the end of the PNC applications, while the other flat remained in the greenhouse. This procedure allowed for separation of the effect of .PNC on seedling response to high- and low-temperature environments near the time of field planting. The first nutrient application was made on 29 Mar. 1989 at the first trueleaf stage. A total of five PNC treatments were used. On 7 Apr. 1989, four replications (flats) of each nutrient treatment were placed in darkness in a cooler at $\approx 2 \mathrm{C}$ from 1900 until $0700 \mathrm{HR}$ for 8 consecutive days. Low-temperature-stressed plants were returned to a greenhouse at a daytime mean of $26 \pm 6 \mathrm{C}$ from 0700 until $1900 \mathrm{HR}$ daily. Another complete set of PNC treatment flats remained in the same greenhouse until field planting and were not exposed to low-temperature treatments. Seedling growth data was taken on 14 Apr., 28 days from seeding on nine randomly chosen plants from each flat.

Influence of NP and low temperatures in the field. Seedlings from each treatment flat were hand-transplanted on 5 Apr. 1988 and 14 Apr. 1989 at the Clemson Univ. Coastal Research and Education Center, Charleston, S.C. Soil type was a Yauhannah loamy fine sand, an Aquic Hapudults. The field was fertilized with (in $\mathrm{kg} \cdot \mathrm{ha}^{-1}$ ) $165 \mathrm{~N}-76 \mathrm{P}-179 \mathrm{~K}$ before planting. Dolomitic limestone was added as indicated by soil tests." Beds on 1.8-m centers were fumigated with methyl bromide at $220 \mathrm{~kg} \cdot \mathrm{ha}^{-1}$ and mulched with $0.3-\mathrm{mm}$ (1.25 mil) black plastic. Plants were spaced $0.5 \mathrm{~m}$ apart within rows, and each 4.6-m-long test plot contained 10 plants. Each treatment was replicated four times in a randomized complete block design. Plots were drip-irrigated as necessary when tensiometers $(30 \mathrm{~cm}$ deep) were at 0.2 $\mathrm{Pa}$ in 1988 and at $0.1 \mathrm{~Pa}$ in 1989 . Tomatoes were staked, tied, suckered, and sprayed with pesticides using standard commercial recommendations (Cook, 1980).

The fruits from the first flower cluster were harvested from a plant in the center of each treatment plot the day before the first harvest to determine if PNC and/or low-temperature exposure affected the weight and quality in the first cluster. All of the remaining fruit were harvested at the breaker stage (Ware and McCollum, 1980). The fruit was graded using USDA standards of small $(<5.5 \mathrm{~cm})$, medium $(5.5-7.0 \mathrm{~cm})$, large $(>7.0$ $\mathrm{cm})$, and cull fruit. The cull fruit was categorized separately by major blemish factors as follows: cracking, blossom-end rot (BER), green shoulders, and seams. There were three weekly harvests in 1988 and four in 1989. Data were analyzed by harvest date and also pooled over the entire harvest season each year. Data analysis was the same as outlined in the greenhouse study.

\section{Results}

Influence of PNC on seedling growth. The effect of $\mathrm{N}$ and $\mathrm{P}$ nutritional conditioning on seedling growth differed between 1988 and 1989. Plant height, stem diameter, leaf number, leaf area, and fresh and dry shoot weights were higher at 200 than at $100 \mathrm{mg} \mathrm{N} /$ liter in 1988, with no further increases above 200 $\mathrm{mg} \cdot \operatorname{liter}^{-1}$ (Table 1). Root dry weight increased with $\mathrm{N}$ from 100 to $300 \mathrm{mg} \cdot \operatorname{liter}^{-1}$. Total chlorophyll content was higher at 300 than at 100 or $200 \mathrm{mg}$ N/liter, substantiating an apparent visual enhancement of greenness with high $\mathrm{N}$.

Plant height, stem diameter, leaf number, leaf area, and fresh and dry shoot weights responded similarly in 1989 as in 1988, but with $\mathrm{N}$ in the range of 50 to $200 \mathrm{mg} \cdot \operatorname{liter}^{-1}$ (Table 1). Total chlorophyll was higher with $200 \mathrm{mg}$ N/liter than at the lower concentrations. Root dry weight increased only with $\mathrm{N}$ from 50 to $100 \mathrm{mg} \cdot$ liter $^{-1}$. Nitrogen interacted with low-temperature exposure to affect all of the variables; however, only $5 \%$ to $8 \%$ of the variation was attributable to this effect, which we considered to be negligible.

Phosphorus PNC affected all of the growth variables measured in 1988 (Table 1). Stem diameter, leaf number, leaf area, fresh shoot weight, and dry shoot and root weights were higher with 40 than with $10 \mathrm{mg}$ P/liter, with no further effect above $40 \mathrm{mg} \cdot$ liter $^{-1}$. Plant height increased with $\mathrm{P}$ concentration from 10 to $70 \mathrm{mg} \cdot$ liter $^{-1}$. Total chlorophyll was lower with 40 than with $10 \mathrm{mg}$ P/liter, with no further decrease at $70 \mathrm{mg} \cdot$ liter $^{-1}$. Phosphorus had less effect in 1989 than in 1988; at $40 \mathrm{mg} \cdot \mathrm{liter}^{-1}$, it increased stem diameter, leaf area, and fresh and dry shoot weights relative to $10 \mathrm{mg} \cdot \operatorname{liter}^{-1}$. The higher $\mathrm{P}$ concentration caused a decrease in total chlorophyll. Phosphorus did not interact with $\mathrm{N}$ or low-temperature exposure to affect any growth variable.

Low temperatures in 1989 significantly reduced all growth variables in comparison to those not exposed to chilling (Table 1).

Influence of PNC and low temperature in the field. Yield and quality of fruit harvested from the first flower cluster were not 
Table 1. Effects of N and P PNC and low temperature on tomato seedling growth.

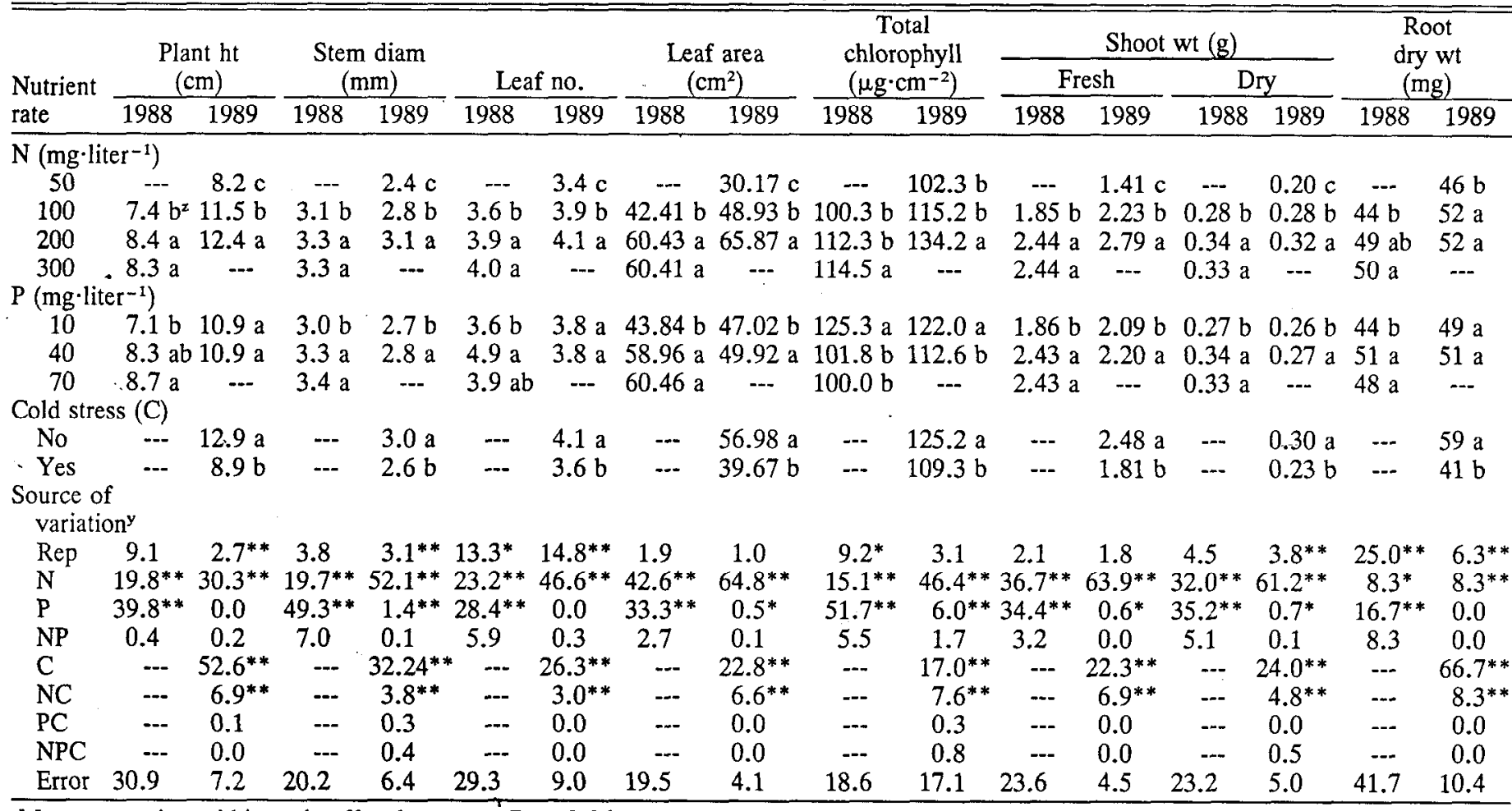

${ }^{2}$ Mean separation within main effect by LSD at $P=0.05$.

${ }^{y}$ Composed of all sources of variation.

*,**F value significant at $P=0.05$ or 0.01 , respectively. Values not followed by asterisks are not significant at $P=0.05$.

affected in 1988 or 1989 by nutrient treatment or Iow-temperature exposure (data not shown).

In 1988, early yield in the first harvest was unaffected by $\mathrm{N}$ and $\mathrm{P}$ regime (data not shown). However, by the last harvest, $\mathrm{N}$ accounted for a major portion of variation and also a significant amount was assigned to the main effect of $\mathrm{P}$, indicating that PNC has long-term effects on productivity (Table 2). In 1988, yields from the third harvest increased by $17 \%$ for $\mathrm{N}$ PNC rates at 200 and $300 \mathrm{mg} \cdot$ liter $^{-1}$ relative to those conditioned with $100 \mathrm{mg} \mathrm{N} /$ liter. Increased P, like N, produced higher yields in the third harvest with $40 \mathrm{mg} \mathrm{N} / \mathrm{liter}$ than with 10; however, increasing $\mathrm{P}$ to $70 \mathrm{mg} \cdot \mathrm{liter}^{-1} \mathrm{did}$ not increase yield further.

Nitrogen PNC in 1989 accounted for a significant portion of variation in early yields in comparison to the other main effects and interactions; however, the effect of N PNC diminished by the last harvest (Table 2). Seedlings conditioned with $\mathrm{N}$ at 200 mg.liter ${ }^{-1}$ yielded more fruit in the first harvest than those conditioned with the 50- or 100-mg.liter ${ }^{-1}$ rates. In the second and third harvests, seedlings conditioned with $\mathrm{N}$ at $100 \mathrm{mg} \cdot \mathrm{liter}^{-1}$ yielded more fruit than those conditioned with $50 \mathrm{mg} \cdot \mathrm{liter}^{-1}$; $\mathrm{N}$ at $200 \mathrm{mg} \cdot \mathrm{liter}^{-1}$ did not increase yield further. Pretransplant conditioning with $\mathrm{N}, \mathrm{P}$, or cold stress had no significant effect by the last harvest.

Analysis of the pooled yields over all harvests in 1988 indicated that total marketable yield was significantly higher at 200 than at $100 \mathrm{mg} \mathrm{N} /$ liter (Table 2); however, $\mathrm{N}$ at $300 \mathrm{mg} \cdot \mathrm{liter}^{-1}$ did not increase yield further. In 1989, total marketable yield from plants conditioned with $\mathrm{N}$ at 100 or $200 \mathrm{mg} \cdot \mathrm{liter}^{-1}$ was significantly greater than $\mathrm{N}$ at $50 \mathrm{mg} \cdot \mathrm{liter}^{-1}$
In 1989, neither P nor low-temperature exposure affected any yield variables (data not shown).

Quality blemishes were significantly affected by PNC in 1989 (Table 3), but not in 1988 (data not shown). BER was a severe problem in 1989, affecting $30 \%$ to $40 \%$ of all cull fruit produced in this growing season. BER was most severe at a PNC rate of $50 \mathrm{mg} \mathrm{N} /$ liter. At $100 \mathrm{mg} \mathrm{N} / \mathrm{liter}$, the incidence of concentric cracking increased in comparison to the other $\mathrm{N}$ rates. The percentage of seamed fruit increased from $2 \%$ to $6 \%$ at 50 and 200 $\mathrm{mg} \mathrm{N} /$ liter. Green shoulders were more common at $200 \mathrm{mg} \mathrm{N} /$ liter than at lower levels. Neither low-temperature exposure nor $P$ had any effect on incidence of fruit blemishes in 1989 (data not shown).

\section{Discussion}

A traditional practice to harden seedlings has included withholding nutrients before transplanting. These practices are thought to be detrimental to the production potential of tomatoes. Our results indicated that high $\mathrm{N}$ and $\mathrm{P}$ PNC enhanced seedling shoot and root growth.

Weston and Zandstra (1989) recommended that $400 \mathrm{mg} \mathrm{N} /$ liter should be considered optimal for the production of large seedlings that produce increased early and total yields. In 1988, $300 \mathrm{mg} \mathrm{N} /$ liter did not yield more fruit than the 200-mg.liter ${ }^{-1}$ PNC rate. We suggested that $\mathrm{N}$ at $50 \mathrm{mg} \cdot \mathrm{liter}^{-1}$ is deficient and may permanently reduce yield potential. Courter et al. (1977) stated that plants overly hardened with water withdrawal, temperature stress, and/or nutrient withdrawal, resume growth slowly and may never fully recover, mature later, and may have reduced yields. 
Table 2. Effects of $\mathrm{N}$ and $\mathrm{P} P N C$ and low temperature on total tomato marketable yield for each harvest. ${ }^{2}$

\begin{tabular}{|c|c|c|c|c|c|c|c|}
\hline \multirow{3}{*}{$\begin{array}{l}\text { Nutrient } \\
\text { rate }\end{array}$} & \multicolumn{7}{|c|}{ Harvest no. } \\
\hline & \multicolumn{2}{|c|}{1988} & \multicolumn{5}{|c|}{1989} \\
\hline & 3 & Total & 1 & 2 & 3 & 4 & Total \\
\hline & & & & $\left(t \cdot h a^{-1}\right)$ & & & \\
\hline \multicolumn{8}{|c|}{$\mathrm{N}\left(\mathrm{mg} \cdot\right.$ liter $\left.^{-1}\right)$} \\
\hline 50 & -- & $\cdots$ & $1.4 \mathrm{~b}$ & $3.2 \mathrm{~b}$ & $8.4 \mathrm{~b}$ & $3.6 \mathrm{a}$ & $16.6 \mathrm{~b}$ \\
\hline 100 & $9.2 b^{y}$ & $21.3 \mathrm{~b}$ & $2.4 \mathrm{~b}$ & $7.2 \mathrm{a}$ & $15.2 \mathrm{a}$ & $4.8 \mathrm{a}$ & $29.6 \mathrm{a}$ \\
\hline 200 & $14.1 \mathrm{a}$ & $29.7 \mathrm{a}$ & $4.6 \mathrm{a}$ & $7.6 \mathrm{a}$ & $14.4 \mathrm{a}$ & $5.8 \mathrm{a}$ & $32.4 \mathrm{a}$ \\
\hline 300 & $14.5 \mathrm{a}$ & $32.7 \mathrm{a}$ & --. & --- & --- &.-- & -- \\
\hline \multicolumn{8}{|c|}{ P (mg $\cdot$ liter $\left.^{-1}\right)$} \\
\hline 10 & $10.6 \mathrm{~b}$ & $23.2 \mathrm{~b}$ & $2.4 \mathrm{a}$ & $6.2 \mathrm{a}$ & $12.8 \mathrm{a}$ & $5.2 \mathrm{a}$ & $26.6 \mathrm{a}$ \\
\hline 40 & $14.1 \mathrm{a}$ & $32.4 \mathrm{a}$ & $3.2 \mathrm{a}$ & $5.8 \mathrm{a}$ & $12.4 \mathrm{a}$ & $4.4 \mathrm{a}$ & $25.8 \mathrm{a}$ \\
\hline 70 & $13.1 \mathrm{ab}$ & $28.2 \mathrm{ab}$ & --- & -- & -- & --- & -- \\
\hline \multicolumn{8}{|c|}{ Cold stress (C) } \\
\hline No & -- & -- & $2.6 \mathrm{a}$ & $6.6 \mathrm{a}$ & $12.4 \mathrm{a}$ & $4.6 \mathrm{a}$ & $26.2 \mathrm{a}$ \\
\hline Yes & $\ldots$ & -- & $3.0 \mathrm{a}$ & $5.6 \mathrm{a}$ & $13.0 \mathrm{a}$ & $5.0 \mathrm{a}$ & $26.6 \mathrm{a}$ \\
\hline \multicolumn{8}{|c|}{$\begin{array}{l}\text { Source of } \\
\text { variation }\end{array}$} \\
\hline Rep & 5.5 & 19.4 & 10.5 & 4.8 & 5.6 & 5.9 & 8.8 \\
\hline $\mathrm{N}$ & $31.6^{* *}$ & $25.9^{* *}$ & $30.0^{* *}$ & $18.4^{*}$ & $15.5^{*}$ & 8.2 & $26.6^{* *}$ \\
\hline $\mathrm{P}$ & $12.3^{*}$ & $16.4^{* *}$ & 2.7 & 0.2 & 0.1 & 1.9 & 0.1 \\
\hline NP & 12.7 & 1.9 & 2.8 & 5.4 & $11.4^{*}$ & 4.2 & 8.9 \\
\hline $\mathrm{C}$ & -.- & --- & 0.6 & 1.3 & 0.1 & 0.3 & 0.0 \\
\hline NC & -- & --- & 0.9 & 3.7 & 0.5 & 1.8 & 0.4 \\
\hline $\mathrm{PC}$ & $-\cdots$ & --- & $5.7^{*}$ & 0.8 & 1.7 & 0.3 & 0.0 \\
\hline NPC & -- & --- & 1.6 & 0.0 & 5.8 & 1.5 & 1.9 \\
\hline Error & 37.9 & 36.4 & 45.3 & 65.4 & 59.5 & 76.1 & 53.2 \\
\hline
\end{tabular}

'1988-First harvest lost to blossom-end rot.

${ }^{y}$ Mean separation within main effect by LSD at $P=0.05$.

'Composed of all sources of variation.

***F value significant at $P=0.05$ or 0.01 , respectively. Values not followed by asterisks are not significant at $P=0.05$ or 0.01 .

Table 3. Effects of $\mathrm{N}$ and P PNC and low temperature on percentage of cull production due to fruit quality blemishes in 1989 .

\begin{tabular}{lcccc}
\hline & \multicolumn{4}{c}{ Percentage of total cull fruit } \\
\cline { 2 - 5 } $\begin{array}{l}\text { Nutrient } \\
\text { rate }\end{array}$ & $\begin{array}{c}\text { Blossom-end } \\
\text { rot }\end{array}$ & $\begin{array}{c}\text { Concentric } \\
\text { cracking }\end{array}$ & Seams & $\begin{array}{c}\text { Green } \\
\text { shoulders }\end{array}$ \\
\hline $\mathrm{N}\left(\mathrm{mg} \cdot \mathrm{liter}^{-1}\right)$ & & & & \\
50 & $40.0 \mathrm{a}^{\mathrm{z}}$ & $16.0 \mathrm{~b}$ & $2.0 \mathrm{a}$ & $8.0 \mathrm{~b}$ \\
100 & $34.0 \mathrm{~b}$ & $21.0 \mathrm{a}$ & $4.0 \mathrm{~b}$ & $9.0 \mathrm{~b}$ \\
200 & $30.0 \mathrm{~b}$ & $18.0 \mathrm{ab}$ & $6.0 \mathrm{c}$ & $12.0 \mathrm{a}$ \\
Source of & & & & \\
variation & & & & \\
Rep & 3.33 & 7.14 & 0.00 & 0.00 \\
$\mathrm{~N}$ & $26.67^{* *}$ & $14.29^{*}$ & $50.00^{* *}$ & $14.29^{* *}$ \\
$\mathrm{P}$ & 0.00 & 7.14 & 0.00 & 0.00 \\
$\mathrm{NP}$ & 3.33 & 0.00 & 0.00 & $14.29^{*}$ \\
$\mathrm{C}$ & 3.33 & 0.00 & 0.00 & 0.00 \\
$\mathrm{NC}$ & 6.67 & 0.00 & 0.00 & 0.00 \\
$\mathrm{PC}$ & 0.00 & 0.00 & 0.00 & 0.00 \\
$\mathrm{NPC}$ & 0.00 & 0.00 & 0.00 & 0.00 \\
Error & 56.67 & 71.43 & 50.00 & 71.43 \\
\hline
\end{tabular}

'Mean separation within main effect by LSD at $P=0.05$.

${ }^{y}$ Composed of all sources of variation.

$* * *$ F value significant at $P=0.05$ or 0.01 , respectively. Values not followed by asterisks are not significant at $P=0.05$.

Our research suggested that concern over the effects of low temperature experienced in the field foIlowing transplanting may be unwarranted with the 'Sunny' tomato. Hurd and Cooper (1970) found that flower initiation in many tomato cultivars started within 3 weeks of cotyledon expansion, coincident with the third oldest leaf being just in excess of $10 \mathrm{~mm}$ Iong. Apparently, in our study, first fruit initials were not affected during the time of low-temperature exposure since temperatures at $2 \mathrm{C}$ would have arrested their development. Low-temperature exposure decreased seedling growth and likely was stressful. Low temperatures are know to slow plant growth and reduce metabolic rates (Salisbury and Ross, 1985). The plants remaining in the greenhouse during this time were apparently able to continue more active growth in response to moderate night temperatures. However, there were no long-term effects of low-temperature exposure on earliness of fruit set, total yields, and fruit quality.

Nitrogen applied at 50 or $100 \mathrm{mg} \cdot \mathrm{liter}^{-1}$ in contrast to 200 mg.liter ${ }^{-1}$ reduced yields. Although cultivar differences probably exist in response to PNC, nutritionally conditioning seedlings with at least $200 \mathrm{mg}$ N/liter may enhance marketable yields relative to lower $\mathrm{N}$ rates. In tomato transplant production, the nutritional regimes used to produce seedlings have long-lasting effects on earliness and total yields. Therefore, a PNC regime combining at least $200 \mathrm{mg} \mathrm{N}$ and $10 \mathrm{mg}$ P/liter should be used to nutritionally condition seedlings during the transplant production phase to promote earlier and higher yields.

\section{Literature Cited}

Brasher, E.P. and K.C. Westover. 1937. The effect on yield of hardening the tomato plant. Proc. Amer. Soc. Hort. Sci. 35:686-689.

Cook, W.C. 1980. Commerical tomato production in South Carolina. Clemson Coop. Ext. Circ. 625.

Courter, J. W., J.S. Vandermark, and B.J. Jacobson. 1977. Growing vegetable transplants. Illinois Coop. Ext. Serv. Circ. 884. 
Dufault, R.J. 1986. Influence of nutritional conditioning on musk- Salisbury, F. and B. Ross. 1985. Plant physiolgy. 3rd ed. Wadsworth melon transplant quality and early yield. J. Amer. Soc. Hort. Sci. 111:698-703.

Hurd, R. and A. Cooper. 1970. The effect of early low temperature treatment on the yield of single inflorescence tomatoes. J. Hort. Sci. 45:19-27.

Melton, R. and R.J. Dufault. 1991. Nitrogen, phosphorus and potassium fertility regimes affect tomato transplant growth. HortScience 26:141-142.

Moran, R. 1982. Formula for determination of chlorophyll pigments extracted with N,N dimethylformamide. Plant Physiol. 69:13761381. Publishing CO., Belmont, Calif.

Ware, G.W. and J.P. McCollum. 1980. Producing vegetable crops. The Interstate Printers and Publishers, Danville, Ill.

Weston, L.A. and B.H. Zandstra. 1989. Transplant age and N and P nutrition effects on growth and yield of tomatoes. HortScience 24:88-90.

Wheaton, T. and L.L. Morris. 1968. Modifications of chilling sensitivity by temperature conditioning. Proc. Amer. Soc. Hort. Sci. 91:529-533.

Wittwer, S.H. and F.G. Teubner. 1957. The effects of temperature and nitrogen nutrition on flower formation in the tomato. Amer. J. Bot. 44:125-129. 